\title{
Primeri bilinmeyen karaciğer metastazlarında ince iğne aspirasyon biyopsi sonuçlarının değerlendirilmesi
}

\author{
Evaluation of the results of fine-needle aspiration biopsy in unknown liver metastasis \\ Elmas KASAP' ${ }^{1}$, Hafize KURT², Semin AYHAN³ ${ }^{3}$, Hakan YÜCEYAR ${ }^{1}$ \\ Celal Bayar Üniversitesi Tıp Fakültesi, ${ }^{1}$ Gastroenteroloji, ${ }^{2} I_{c ̧}$ Hastalıkları, ${ }^{3}$ Patoloji Bilim Dalı, Manisa
}

\begin{abstract}
Giriş ve Amaç : Önemli bir sağlık sorunu olan malign hastallkların \% 5 'ini primeri bilinmeyen metastatik tümörler oluşturmakta ve primeri bilinmeyen metastatik tümörlerin ortalama \%33'ünde de karaciğer metastazı saptanmaktadır. Bu nedenle histopatolojik tanı önem kazanmaktadır. Calıșamızın amacı karaciğerde kitle ile başvuran olguların karaciğer biyopsisi ile metastazı kanıtlananların histopatolojik verilerinin retrospektif olarak değerlendirilmesidir. Gereç ve Yöntem: Celal Bayar Universitesi Tip Fakültesi Gastroenteroloji Kliniğine Ocak 2000-Ağustos 2009 tarihleri arası karaciğerde kitle ile başvuran ve ultrasonografi eşliğinde 'free hand Tru-cut' tekniği ile 18Gx200 mm-22 mm type iğneleri kullanılarak yapılan ince iğne aspirasyon biyopsisi ile metastaz tanisı alan 58 olgunun histopatoloji sonuçlan retrospektif olarak değerlendirilmiştir. Çalışma'ya dahil edilen 58 olgunun 40'ı erkek, 18'i kadındır. 58 olgunun ortalama yaşı 63,05 (32-86)'tir. Olgular yaş, cinsiyet, histopatolojik ve sitolojik tanıları ve eğer saptanmışsa primer odakları açısından değerlendirilmiştir. Bulgular: Metastatik tümör saptanan olgularnn 43 (\%72)'ünde adenokarsinom metastazı, 4 (\%6,8)'ünde küçük hücreli karsinom, 4 (\%6,8)'ünde indiferan tümör, 3 (\%5,2)'ünde nöroendokrin tümör saptanmıștır. Olgularnn \%43, I'inde primer odak saptanmıştır. Primer odak olarak en sık kolon (\%60), ikinci sıklikla pankreas (\%16) ve 3. siklikla safra kesesi ve mide (\%12) saptanmıştır. Sonuç: Ince iğne aspirasyon biyopsisi karaciğer metastazlarnnın histopatolojisini belirlemede kullanılan önemli bir yöntemdir.
\end{abstract}

Anahtar kelimeler: Karaciğer tümörleri, tümörler, bilinmeyen primer, biyopsi, ince-iğne

\section{GİRISS}

Primeri bilinmeyen tümörler \%40 oranında karaciğerde kitle ve abdominal bulgularla karşımıza çıkarlar. Primeri bilinmeyen tümörlerin prognozu oldukça kötüdür (1). Karaciğer metastazlı olgularda beklenen yaşam süresi ortalama 6 ay kadardır (1). Karaciğer, karın içindeki kan yoluyla metastazlar ile diyafram üzerindeki tümörlerin en sık metastaz yaptığı alandır (2). Primer karaciğer tümörü olduğu düşünülen ölen olguların \%36-42'sinde tümörün metastatik karaciğer tümörü olduğu görülmüştür (2). Metastatik karaciğer tümörleri primer karaciğer tümörlerinden yaklaşık 20-40 kez daha fazla görülürler (1,2). Görüntüleme yöntemleri ile karaciğer kitlelerini saptamak ve ince iğne aspirasyon sitolojisi (IIAS) ile tanı koymak mümkündür (3). Önemli bir sağlık sorunu olan malign hastalıkların \%5'ini primeri bilinmeyen metastatik tümörler (PBMT) oluşturmakta ve PBMT'lerin ortalama \%33'ünde de karaciğer metastazı saptanmaktadır $(4,5)$. Primeri bilinmeyen
Background and Aims: Five percent of all cancers in patients are unknown primary carcinoma, and 33\% of the patients with unknown primary carcinoma have liver metastasis. Thus, the histopathological diagnosis is important. The aim of this study was to evaluate the histopathological data with liver metastasis retrospectively. Materials and Methods: Fifty-eight patients (40 males, 18 females) with unknown liver mass who were hospitalized in Celal Bayar University Faculty of Medicine, Gastroenterology Department between January 2000 and August 2009 were reviewed retrospectively. The biopsy was taken by Tru-cut technique with $18 \mathrm{G}$ X $200 \mathrm{~mm}-22 \mathrm{~mm}$ needle guided by ultrasonography. The mean age of the 58 patients was 63.05 (32-86) years. Age, sex, histopathological/cytological diagnoses, and primary focus of the malignancy, if found, were evaluated. Results: The histopathological spectrum of liver metastasis included: 43 (72\%) adenocarcinomas, 4 (6.8\%) small cell carcinomas, 4 (6.8\%) indifferent tumors, and 3 (5.2\%) neuroendocrine tumors. Primary focus of malignancy was found in $43.1 \%$ of patients as: $60 \%$ colon, $16 \%$ pancreas and $12 \%$ stomach and gallbladder. Conclusions: Fine-needle aspiration biopsy of liver metastasis is a method used in determining histopathology.

Key words: Liver neoplasms, neoplasms, unknown primary, biopsy, fineneedle

metastatik karaciğer tümör (PBMKT)'ü olanların yaklaşık \%80'ini adenokarsinomlar oluşturmakta ve kötü prognozla seyretmektedirler $(4,6,7)$. Ancak nöroendokrin hücre kökenli olanlar gibi bazı tümörler tedaviye iyi yanıt vermekte, daha uzun yaşam süresine sahip olabilmekte ve bu nedenle de PBMKT'lü olgularda histopatolojik tanı önem kazanmaktadır (3). Ince iğne aspirasyon biyopsisi karaciğerde primer maligniteler ile metastatik lezyonları ayırmada yararlı bir yöntemdir (8). Çalışmamızda, karaciğerde kitle ile başvuran olguların, karaciğer ince iğne biyopsisi ile metastazı kanıtlananlarda histopatolojik veriler retrospektif olarak değerlendirilmiştir.

\section{GEREC VE YÖNTEM}

Celal Bayar Üniversitesi Tıp Fakültesi Hastanesi Gastroenteroloji Kliniği'ne Ocak 2000-Ağustos 2009 tarihleri arasında karaciğerde kitle ile başvuran ve biyopsi yapılarak patoloji ra- 
porlarında metastatik tümör tanısı alan 58 olgu retrospektif olarak değerlendirilmiştir. Olgular yaş, cinsiyet, histopatolojik ve sitolojik tanıları ve eğer saptanmışsa primer odakları açısından değerlendirilmiştir. Primer odak araştırılması için akciğer grafisi, üst ve alt gastrointestinal endoskopisi, erkek hastalarda prostat tümörüne yönelik tetkikler, kadınlarda meme muayenesi ve radyolojik tetkiki, tüm batın ve toraks tomografisi yapılmış olan olgular çalışmaya dahil edilmişstir. Olguların tümünden biyopsi öncesi onay formu alınmıştır Karaciğer ince iğne biyopsisi koagülasyon testleri ultrasonografi eşliğinde free hand 6-8. interkostal aralıktan tru-cut tekniği ile TSK ACECUT marka 18Gx200 mm-22 mm type iğneleri kullanılarak yapılmıştır. Menghini tekniği ise Braun marka Hepafix 17G/1.4 mm iğneleri kullanılarak yapılmıştır. Histopatolojik tanısı konulamadığı için bir olguda 2. kez biyopsi yapılmış diğer olguların tanıları tek biyopsi ile konmuştur.

\section{Etik Kurul}

Bu çalışma ile ilgili etik kurul onayı Celal Bayar Üniversitesi Tip Fakültesi Dekanlığı Bilimsel Araştırmalar Etik Kurulu Başkanlığı'nın 02/08/2010 tarihli 0184 sayılı onayı ile gerçekleştirilmiştir.

\section{BULGULAR}

Kırkı erkek, 18'i kadın, 58 olgu çalışmaya alınmıştır. Erkek olguların ortalama yaşı 63,2 (32-86), kadın olguların ortama yaşı 62,9 (43-79)'dur.

Ellisekiz olguya ince iğne aspirasyon biyopsisi yapılmıştır. Olguların 43 (\%72)'ünde adenokarsinom metastazı, $4(\% 6,8)$ 'ünde küçük hücreli karsinom, 4 (\%6,8)'ünde indiferan tümör, 3 $(\% 5,2)$ 'ünde nöroendokrin tümör saptanmıştır. Skuamöz hücreli karsinom tanısı alan bir hastanın küçük hücreli karsinom ile tam ayrımı yapılamamıs ve daha çok skuamöz lehine yorumlanmıştır. Bir olguda alınan biyopside malign hücreler saptanmış fakat yetersiz materyal olması nedeniyle 2. kez biyopsi yapılarak nöroendokrin tümör tanısı konulmuştur (Tablo 1).

Olguların \%43, l'inde primer odak saptanmıştır. Primer odak olarak en sık kolon (\%60), ikinci sıklikla pankreas (\%16) ve 3. sıklıkla safra kesesi ve mide (\%12) saptanmıştır (Tablo 2).

\section{TARTIŞMA}

Tüm malign hastalıklar içerisinde sıklığı \%5 olan PBMT'lerin yaklaşık \%33'ünde karaciğer metastazı saptanır $(4,5)$. Karaciğer metastazları içerisinde en sk \%60-80 oranla adenokarsinom görülür ki bunların prognozu oldukça kötüdür (4-6,9). Metastazlar içerisinde daha iyi prognozlu olan nöroendokrin tümörler ise $\% 5,2$ oranında görülür $(5,6)$. Çalışmamızda literatüre göre hemen hemen aynı sıklıkta adenokarsinom ve nöroendokrin tümör saptanmıştır. Benzer çalışma Tekin ve ark. tarafından yapılmış ve adenokarsinom sıklığ $\% 60$, nöroendokrin tümör sıklı̆̆ \%18 oranında saptanmıştır. Bizim çalışmamızda ise ade-

$\begin{array}{lcc}\text { Tablo 1. Ince iğne biyopsisi sonrası histaopatolojik tanılar } \\ \text { Histopatolojik tanı } & \mathbf{n} & \% \\ \text { Adenokarsinom } & 43 & 74,2 \\ \text { Küçük hücreli karsinom } & 4 & 6,8 \\ \text { Indiferan malign tümör } & 4 & 6,8 \\ \text { Nöroendokrin tümör } & 3 & 5,2 \\ \text { Müsinöz adenokarsinom } & 2 & 3,4 \\ \text { Skuamöz hücreli karsinom?* } & 1 & 1,8 \\ \text { Taşlı yüzük hücreli } & 1 & 1,8 \\ \text { Toplam } & 58 & 100\end{array}$

*Küçük hücreli ile ayrımı tam yapılamamıştır.

\begin{tabular}{|lcc|}
\hline Tablo 2. Primer odağı saptanan olgular & \\
\hline Primer odak & $\mathbf{n}$ & $\%$ \\
\hline Akciğer & 1 & 4 \\
\hline Kolon & 15 & 60 \\
Safra kesesi & 3 & 12 \\
Pankreas & 4 & 16 \\
Mide & 3 & 12 \\
Meme & 1 & 4 \\
Papilla vateri & 1 & 4 \\
Toplam & 25 & 100
\end{tabular}

nokarsinom daha sık görülürken nöroenokrin tümöre ise daha az rastlanmıştır. Ankara Üniversitesi'nde yapılan benzer bir çalışmada ise adenokarsinom oranı \%62,93 oranında bulunmuştur (10). Yine bizim çalışmamızda adenokarsinom bu çalışmaya kıyasla daha yüksek saptanmışır. Hogan ve arkadaşlarının yaptı̆̆ çalışmada \%78 adenokarsinom, \%7 oranında nöroendokrin tümör; Hess ve ark.'nın çalışmasında ise \%80 adenokarsinom, \%4 nöroendokrin tümör saptanmıştır $(5,6)$.

Primer odağın bulunması açısından baktığımızda tüm olgularımızın \%43,1'inde primer odak saptanmıştır. Kolon adenokarsinomlar1 \%60 oranla en sik saptanan primer odak iken, pankreas \%16 ile ikinci sıradadır. Nöoroendokrin tümörlü olgularımızdan da l'inde pankreasta primer tümör saptanmıştır.

Literatürde primer odak bulma sıklı̆̆ $\% 6-40$ 'dır $(3,6,8,10)$. Çalışmamızda olguların \%43,1'inde primer odak saptanmıştır. Literatüre oranla primer odak bulma sıklığımız küçük bir oran da olsa daha fazladır. Ege Üniversitesi’nde yapılan bir çalışmada da \%40 olgunun primer odağı saptanabilmiştir. Bu çalışmada \%23,5 oranında akciğer ve aynı oranda kolon primer odak olarak saptanmıştır (3). Çalışmamızda ise kolon sıklığı daha fazla iken, akciğer daha az oranda primer odak olarak saptanmıştır. Yine Ege Üniversitesi'nde yapılan çalışmada \%17,6 ile safra kesesi, \%11,8 ile pankreas primer odak olarak saptanmıştır (3). Bizim çalışmamızda ise pankreas $\% 16$, safra kesesi \%12 oraninda primer odak olarak bulunmuştur. Hogan ve ark. yaptığı çalışmada \%18, Gaber ve ark. $\% 9,5$, Lortholary ve ark. \%6 oranında primer odak saptamıs$\operatorname{lardır}(6,8,10)$ 


\section{SONUÇ}

Primeri bilinmeyen tümörlü olguların üçte birinde karaciğer metastazı görülmektedir. Karaciğer metastazlarının histopato-

\section{KAYNAKLAR}

1. Abbruzzese JL, Abbruzzese MC, Hess KR, et al. Unknown primary carcinoma: natural history and prognostic factors in 657 consecutive patients. J Clin Oncol 1994; 12: 1272-80.

2. Douglas R. LaBrecque. Mass lesions and neoplasia of the liver. In: Friedman SL, McQuaid KR, Grendell JH, edt. Current diagnosis and treatment in gastroenterology. 2nd ed. New York: Mc Graw-Hill Companies; 2007; 697-726

3. Arslan H, Dilek FH, Sakarya ME, et al. Karaciğer kitle lezyonlarında US eşliğinde yapılan kesici iğne biyopsileri. Van Tıp Dergisi, 1998; 3: 152 4.

4. Tekin F, Kasap E, Ersöz G, et al. Ilk bașvuruda primer odağı bilinmeyen metastatik karaciğer tümörlü 43 olgunun irdelenmesi. Akademik Gastroenteroloji Dergisi 2005; 4: 4-6.

5. Hess KR, Abbruzzese MC, Lenzi R, et al.. Classification and regression tree analysis of 1000 consecutive patients with unknown primary carcinoma. Clin Can Res 1999; 5: 3403-10 lojik tanısını koymada ince iğne aspirasyon biyopsisi diğer invaziv ve noninvaziv yöntemlerle tanı konulamayan tümörlü olgularda kullanılan önemli yöntemlerden biridir.

6. Hogan BA, Thornton FJ, Brannigan M, et al. Hepatic metastases from an unknown primary neoplasm (UPN): survival, prognostic indicators and value of extensive investigations. Clin Radiol 2002; 57: 1073-7.

7. Mousseau M, Schaerer R, Lutz JM, et al. Hepatic metastasis of unknown primary site. Bull Cancer 1991; 78: 725-36.

8. Gaber AO, Rice P, Eaton $\mathrm{C}$, et al. Metastatic malignant disease of unknown origin. Am J Surg 1983; 145: 493-7.

9. Soyuer I, Ekinci C, Kaya M, Bahar K. The value of fine needle aspiration biopsy in the diagnosis of metastatic liver tumours. Turk J Gastroenterol 2002; 13: 78-82.

10. Lortholary A, Abadie-Lacourtoisie S, Guerin O, et al. Cancers of unknown origin: 311 cases. Bull Cancer 2001; 88: 619-27. 